\title{
Pembelajaran Daring Melalui Game Edukasi Quizizz Terhadap Hasil Belajar Fisika
}

\author{
Nurfadilah*, Dian Pramana Putra, Riskawati \\ Program Studi Pendidikan Fisika, Universitas Muhammadiyah Makassar \\ *Email: nurfadilah@unismuh.ac.id
}

Received: 12 Agustus 2021; Accepted: 13 September 2021; Published: 23 Desember 2021 DOI: http://dx.doi.org/10.29303/jpft.v7i2.2870

\begin{abstract}
The type of research used Pre-Experimental Designs research. The objectives of this research are: 1) Describe the learning outcomes of students in class X MIPA at SMA Negeri 5 Bone before and after the implementation of online learning with the educational game Quizizz in learning; 2) Describe the improvement in learning outcomes of students in class X MIPA at SMA Negeri 5 Bone before and after the implementation of online learning using the Quizizz educational game in learning. The samples in this study were students of class X MIPA 1 SMA Negeri 5 Bone which consisted of 31 students. The sampling technique in this study used a purposive sampling technique. The data collection technique used to collect data and in this study was by the meaning of a test consisting of a pretest and posttest in the form of multiple choices. The results of the descriptive analysis in this study showed that the scores obtained by students in the posttest were much higher than the scores obtained in the pretest. So, there is an increase in student learning outcomes before and after being taught by applying the Quizizz educational game, where the increase is in the moderate category. So it can be concluded that by utilizing the Quizizz educational game in learning activities students will focus on the material discussed with the aim of being able to answer quiz questions through the application of online learning assisted by the Quizizz educational game which is given at the end of the lesson.
\end{abstract}

Keywords: Games; Learning outcomes ; Quizizz Education

\section{PENDAHULUAN}

Pendidikan yang berkualitas adalah pendidikan yang mampu mengolah kemampuan peserta didik yang disesuaikan dengan perkembangan teknologi yang sangat pesat seperti sekarang ini. Kemajuan teknologi yang semakin pesat berdampak pada proses pelaksanaan pembelajaran di kelas. Selain sumber informasi yang mudah diakses, para pendidik juga dihadapkan dengan peserta didik yang lebih modern atau yang sering disebut sebagai generasi milenial yang tentunya memiliki karakter yang inovatif, kompetitif, dan tentu akrab dengan teknologi. Oleh karena itu diperlukan metode pembelajaran yang harus disesuaikan dengan karakteristik peserta didik tersebut.

$$
\text { Pendidik dapat melakukan }
$$
pembelajaran menggunakan metode $E$ learning atau yang biasa disebut daring. Pembelajaran daring merupakan pendidikan formal yang diselenggarakan oleh sekolah dimana peserta didik dan pendidik berada dilokasi terpisah sehingga memerlukan sistem telekomunikasi interaktif untuk menghubungkan keduanya diantaranya melalui perangkat komputer ataupun smartphone android (Arsyad, 2014).

Dampak positif dari perkembangan teknologi terhadap dunia pendidikan yaitu peserta didik dapat memperoleh pengetahuan kapan pun dan dimana pun walau tanpa bantuan pendidik sekalipun karena mudahnya mengakses informasi dengan memanfaatkan teknologi. Sistem pembelajaran yang seperti ini biasa dikatakan sistem pembelajaran e-learning atau daring. Berbagai fasilitas multimedia berbasis IT dapat dimanfaatkan agar proses pembelajaran menjadi lebih menarik. Berbagai aplikasi pembelajaran menarik baik gratis maupun berbayar sudah terseda secara luas dan bisa dimanfaatkan secara 
maksimal oleh peserta didik maupun pendidik.

Menurut Ramadhani, (2020) sistem pembelajaran daring mampu memudahkan peserta didik dan pendidik untuk mengakses pembelajaran tanpa harus bertatap muka langsung apalagi dimasa pandemik covid-19 seperti sekarang. Dimana semua tingkatan pendidikan bahkan hingga perguruan tinggi pembelajaran tatap muka harus ditiadakan mengingat penyebaran covid-19 yang semakin meningkat dan mengharuskan masyarakat untuk melakukan pembatasan sosial (social distancing).

Untuk keberlangsungan proses pendidikan dan dalam rangka memutus mata rantai penyebaran covid-19 maka pelaksanaan pembelajaran harus disesuaikan dengan kebijakan pemerintah nomor 21 tahun 2020 tentang pembatasan sosial berskala besar dalam rangka percepatan penanganan Corona Virus Disease (COVID19). Kegiatan pembelajaran semua jenjang pendidikan dilaksanakan di rumah peserta didik masing-masing dengan memanfaatkan teknologi yang ada. Pendidik dapat melakukan pembelajaran menggunakan metode E-learning atau yang biasa disebut daring. Sistem pembelajaran dilaksanakan melalui perangkat komputer ataupun smartphone android.

Fisika merupakan salah satu bagian dari sains atau IPA yang berkaitan dengan cara mencari tahu tentang berbagai fenomena alam secara sistematis yang pembelajarannya bukan hanya sekedar penguasaan fakta-fakta, konsep-konsep atau prinsip-prinsip saja, tetapi juga merupakan suatu proses penemuan. Jadi, fisika merupakan ilmu pengetahuan alam yang berupa fakta-fakta, prinsip atau konsep yang dalam pengajarannya membutuhkan cara tertentu untuk memikat peserta didik agar terlibat aktif dalam pembelajaran (Said et al., 2015; Nurwahid, (2017).
Hingga saat ini hal yang muncul dalam benak peserta didik ketika mendengar kata fisika yaitu pelajaran yang penuh dengan rumus-rumus yang sulit dipecahkan dan konsep atau prinsip yang sulit dimengerti. Hal inilah yang membuat peserta didik kurang berminat terhadap pembelajara fisika, yang akhirnya berdampak pada hasil belajar peserta didik. Oleh karena itu, dibutuhkan alternatif pembelajaran yang mampu menjadikan pembelajaran fisika menjadi pembelajaran yang menyenangkan. Salah satunya adalah menggunakan layanan aplikasi yang sudah disediakan oleh pihak ketiga yaitu aplikasi Quizizz yang dapat digunakan oleh pendidik untuk membuat pembelajaran fisika lebih menarik dimata peserta didik. Quizizz merupakan sebuah web-tool untuk membuat permainan kuis interaktif yang digunakan dalam pembelajaran yang dapat diakses secara luas oleh peserta didik tanpa harus bertatap muka langsung. Quizizz juga dapat memberikan data dan statistik tentang kinerja peserta didik. Pendidik dapat melacak berapa peserta didik yang menjawab pertanyaan yang telah dibuat (Pohan, 2020).

Pemanfaatan game edukatif seperti Quizizz ini telah diciptakan cukup lama namun pemafaatannya dalam dunia pendidikan masih jarang. Padahal penggunaan game interaktif ini sangat mudah digunakan dan hasil penilaian yang cukup cepat sehingga dapat memudahkan pekerjaan pendidik dalam hal melakukan penilaian hasil belajar peserta didiknya. Sedangkan bagi peserta didik pemberian soal dalam bentuk game interaktif dengan memanfaatkan android tentu dapat menarik minat peserta didik untuk mengikuti pembelajaran, apalagi pada pembelajaran fisika yang dianggap pelajaran yang membosankan bagi peserta didik. Dengan menarik minat peserta didik dengan pemanfaatan game Qiuzizz ini tentu akan 
berdampak pada hasil belajar fisika peserta didik (Purba, 2019; Sulastri et al., 2019; Yana et al., 2019).

Berdasarkan hasil observasi yang telah dilakukan diperoleh bahwa ternyata hasil belajar peserta didik di SMA Negeri 5 Bone masih tergolong rendah. Hal tersebut dikarenakan beberapa faktor diantaranya yaitu penyajian materi pembelajaran masih terbilang monoton. Adapun pada model pembelajaran yang digunakan oleh guru mata pelajaran sudah disesuaikan dengan protokol kesehetan yaitu tidak melakukan pembelajaran tatap muka dikarenakan social distancing. Dimana model pembelajaran yang digunakan yaitu pembelajaran berbasis daring (dalam jaringan) atau yang biasa disebut sebagai pembelajaran jarak jauh. Namun penyajian soal latihan dan evaluasi pembelajaran yang digunakan masih berbentuk file microsoft word atau pdf yang dibagikan kepada peserta didik secara online. Dengan sistem evaluasi yang seperti ini tentu belum cukup evektif untuk meningkatkan hasil belajar peserta didik dikarenakan dengan bentuk evaluasi yang seperti ini tidak menutup kemungkinan antar peserta didik saling bekerjasama dalam menyelesaikan soal-soal yang diberikan kepadanya.

Pemanfaatan game edukatif seperti Quizizz ini telah dilakukan oleh peneliti sebelumnya seperti (Setiawan, 2019; Citra \& Rosy, 2020; Mulatsih, 2020) mengemukakan bahwa terdapat peningkatan responsif terhadap hasil belajar kognitif peserta didik pada pembelajaran matematika materi sistem persamaan linear tiga variable di SMA Negeri 15 Semarang. Sehingga peneliti ingin menerapkan game edukasi Quizizz ini pada pembelajaran fisika dengan menempatkan game edukasi Quizizz bukan pada posttest seperti peneliti sebelumnya, melainkan menempatkan game edukasi
Quizizz ini pada latihan soal tiap akhir pembelajaran.

Berdarkan latar belakang masalah yang telah diuraikan sebelumnya, maka peneliti berinisiatif untuk melakukan penelitian yang berjudul "Pembelajaran Daring Melalui Game Edukasi Quizizz Terhadap Hasil Belajar Fisika”.

\section{METODE PENELITIAN}

Jenis penelitian yang digunakan dalam penelitian ini yaitu penelitian PreExperimental Designs (Sugiyono, 2017). Adapun yang menjadi sampel dalam penelitian ini adalah peserta didik kelas $\mathrm{X}$ MIPA 1 SMA Negeri 5 Bone yang terdiri dari 31 peserta didik. Teknik pengambilan sampel dalam penelitian ini menggunakan teknik purposive sampling. Dalam penelitian ini menggunakan instrumen yaitu berupa tes hasil belajar dimana instrumen berupa multiple chice (pilihan ganda), di mana jawaban pada masing-masing item berupa lima alternatif pilihan dengan satu jawaban tepat. Teknik pengumpulan data yang digunakan dalam pengumpulan data penelitian ini adalah dengan cara tes yang terdiri dari pretest dan posttest dalam bentuk pilihan ganda. Data yang diperoleh dari hasil penelitian ini dianalisis dengan menggunakan teknik analisis deskriptif dan analisis uji N-Gain. Dengan menggunakan faktor Hake berikut:

$$
\langle g\rangle=\frac{S_{\text {post }}-S_{\text {pre }}}{S_{\text {maks }}-S_{\text {pre }}}
$$

(Riduwan, 2015)

\section{HASIL DAN PEMBAHASAN Hasil}

\section{a. Hasil Analisis Deskriptif Hasil Belajar Peserta Didik}

Data dalam penelitian ini diperoleh melalui pemberian pretest dan posttest yang dilaksanakan dengan menggunakan instrument tes yang sama yang disajikan 
dalam bentuk plihan ganda sebanyak 30 soal. Dimana tes yang digunakan merupakan hasil dari validasi dan uji coba atau uji lapangan. Pretest diberikan sebelum memberikan perlakuan untuk mengukur kemampuan awal peserta, kemudian menerapkan game edukasi Quizizz pada pembelajaran selama tiga pertemuan atau sampai satu kompetensi dasar terselesaikan. Selanjutnya diberikan posttest untuk mengukur hasil belajar peserta didik.

Tabel 1. Skor Hasil Belajar Peserta Didik Sebelum Dan Setelah Diterapkannya Game Edukasi Quizizz

\begin{tabular}{lcc}
\hline \multirow{2}{*}{\multicolumn{1}{c}{ Statistik }} & \multicolumn{2}{c}{ Skor Statistik } \\
\cline { 2 - 3 } & Pretest & Posttest \\
\hline Ukuran sampel & 31 & 31 \\
Skor tertinggi & 19 & 29 \\
Skor terendah & 4 & 7 \\
Skor ideal & 30 & 30 \\
Rentang skor & 15 & 22 \\
Skor rata-rata & 13,42 & 23,98 \\
Standar deviasi & 4,20 & 4,70 \\
\hline
\end{tabular}

Berdasarkan Tabel 1 di atas dapat diliat hasil belajar fisika peserta didik sebelum dan setelah diajar dengan menerapkan game edukasi Quizizz pada pembelajaran. Berdasarkan sampel yang telah ditelti, diperoleh bahwa hasil belajar fisika peserta didik kelas X MIPA di SMA Negeri 5 Bone sebelum diajar dengan menerapkan game edukasi Quizizz pada pembelajaran, skor tertinggi yang diperoleh adalah 19 dan skor terendah adalah 4 dari skor ideal 30 yang mungkin dicapai, sedangkan skor rata-rata yang diperoleh adalah 13,42 dengan standar deviasi 4,20 dan setelah diajar dengan menerapkan game edukasi Quizizz menunjukkan skor tertinggi yang diperoleh adalah 29 dan skor terendah adalah 7 dari skor ideal 30 yang mungkin dicapai, sedangkan skor rata-rata yang diperoleh adalah 23,98 dengan standar deviasi 4,70.

\section{b. Hasil Analisis Data Pretest}

Setelah skor hasil belajar fisika peserta didik kelas X MIPA di SMA Negeri 5 Bone dianalisis menggunakan presentase pada distribusi frekuensi maka diperoleh hasil yang disajikan dalam tabel berikut:

Tabel 2. Distribusi Frekuensi dan Presentase Skor Hasil Belajar Peserta Didik Pada Pretest

\begin{tabular}{|c|c|c|}
\hline Skor & $f_{1}$ & Persentase $(\%)$ \\
\hline $4-6$ & 3 & 10 \\
\hline $7-9$ & 2 & 6 \\
\hline $10-12$ & 7 & 23 \\
\hline $13-15$ & 7 & 23 \\
\hline $16-18$ & 10 & 32 \\
\hline $19-21$ & 2 & 6 \\
\hline$\sum$ & 31 & 100 \\
\hline
\end{tabular}

Data distribusi frekuensi pretest pada Tabel 2 terlihat bahwa skor hasil belajar fisika peserta didik pada pretest dalam rentang skor 4-6 terdapat 2 peserta didik, rentang 7-9 terdapat 3 peserta didik, rentang 10-12 terdapat 6 peserta didik, rentang 13-15 terdapat peserta didik, pada rentang 16-18 terdapat 10 peserta didik dan pada rentang 19-21 terdapat 2 peserta didik.

Berikut merupakan data frekuensi preetest yang disajikan dalam bentuk diagram batang:

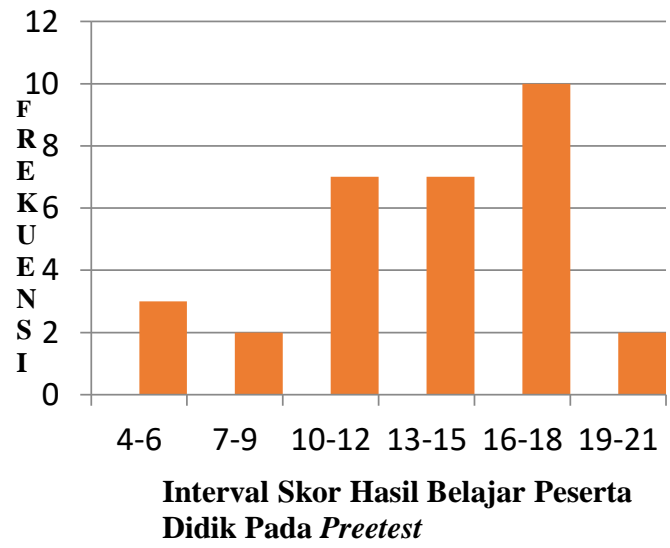

Gambar 1. Diagram Distribusi Frekuensi Kumulatif dan Persentasi Skor Hasil Belajar Peserta Didik pada Pretest 


\section{c. Hasil Analisis Data Posttest}

Berdasarkan data yang diperoleh dari hasil belajar peserta didik setelah diterapkannya game edukasi Quizizz pada pembelajaran yang kemudian dianalisis menggunakan analisis distribusi frekuensi dan persentase skor hasil belajar, dapat dilihat pada tabel 3 berikut

Tabel 3. Distribusi Frekuensi Dan Persentase Skor Hasil Belajar Peserta Didik Pada Posttest

\begin{tabular}{|c|c|c|}
\hline Skor & $f_{1}$ & Persentase $(\%)$ \\
\hline $7-10$ & 1 & 3 \\
\hline $11-14$ & 0 & 0 \\
\hline $15-18$ & 3 & 10 \\
\hline $19-22$ & 4 & 13 \\
\hline $23-26$ & 13 & 42 \\
\hline $27-30$ & 10 & 32 \\
\hline$\sum$ & 31 & 100 \\
\hline
\end{tabular}

Berikut merupakan data frekuensi posttest yang disajikan dalam bentuk diagram batang:

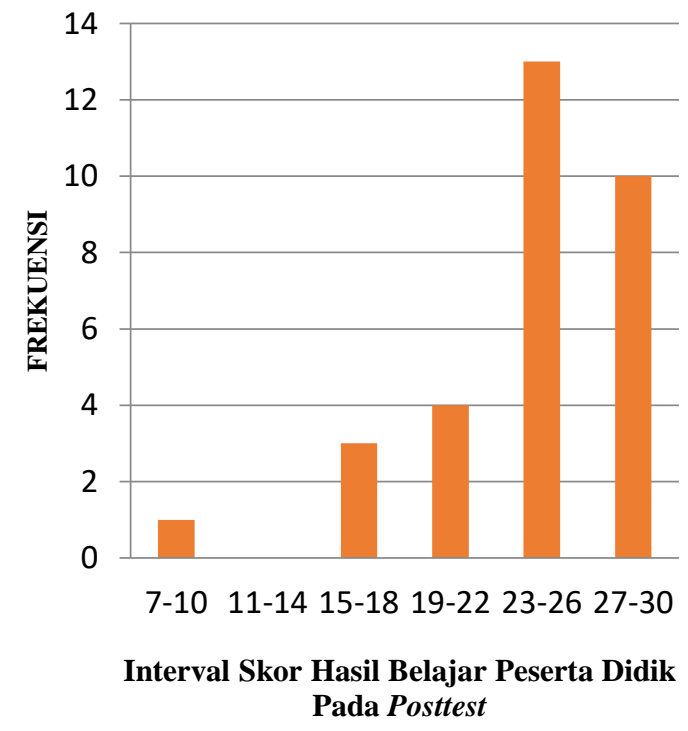

Gambar 2. Diagram Distribusi Frekuensi Kumulatif dan Persentasi Skor Hasil Belajar Peserta Didik pada Posttest

Data distribusi frekuensi posttest pada Tabel 3 terlihat bahwa skor hasil belajar fisika peserta didik pada posttest dalam rentang skor 7-10 terdapat 1 peserta didik, rentang 11-14 tidak terdapat peserta didik, rentang 15-18 terdapat 3 peserta didik, rentang 19-22 terdapat 4 peserta didik, pada rentang 23-26 terdapat 13 peserta didik dan pada rentang 27-30 terdapat 10 peserta didik. Jadi dapat disimpulkan bahwa skor tertinggi berada pada rentang 27-30 sedangkan skor terendah berada pada rentang 7-10.

Tabel 4. Distribus Interval Skor Hasil Belajar Peserta Didik pada Pretest Dan Posttest

\begin{tabular}{|c|c|c|c|c|c|}
\hline \multirow{2}{*}{$\begin{array}{c}\text { Interval } \\
\text { Skor }\end{array}$} & \multicolumn{2}{|c|}{ Pretest } & \multicolumn{2}{|c|}{ Posttest } & \multirow{2}{*}{ Kategor } \\
\hline & $\mathrm{F}$ & $(\%)$ & F & $(\%)$ & \\
\hline $0-6$ & 3 & 10 & 0 & 0 & $\begin{array}{l}\text { Sangat } \\
\text { Rendah }\end{array}$ \\
\hline $7-12$ & 9 & 29 & 1 & 3 & Rendah \\
\hline $13-18$ & 17 & 55 & 3 & 10 & Sedang \\
\hline $19-24$ & 2 & 6 & 10 & 32 & Tinggi \\
\hline $25-30$ & 0 & 0 & 17 & 55 & $\begin{array}{l}\text { Sangat } \\
\text { tinggi }\end{array}$ \\
\hline
\end{tabular}

Dari tabel 4 dapat diketahui bahwa skor hasil belajar fisika peserta didik sebelum diterapkannya game edukasi Quizizz, pada pemberian pretest hanya terdapat 2 peserta didik yang berada pada kategori tinggi, 17 peserta didik berada pada kategori sedang, 9 peserta didik berada pada kategori rendah, dan 3 peserta didik berada pada kategori sangat rendah. Sedangkan skor hasil belajar peserta didik setelah diterampakannya game edukasi Quizizz, pada pemberian posttest terdapat 17 peserta didik berada pada kategori sangat tinggi, 10 peserta didik berada pada kategori tingg, 3 peserta didik berada pada kategori sedang, 1 peserta didik berada pada kategori rendah dan tidak ada peserta didik yang berada pada kategori sangat rendah.

Berikut merupakan data frekuensi hasil pretest dan posttest yang disajikan dalam bentuk diagram batang: 


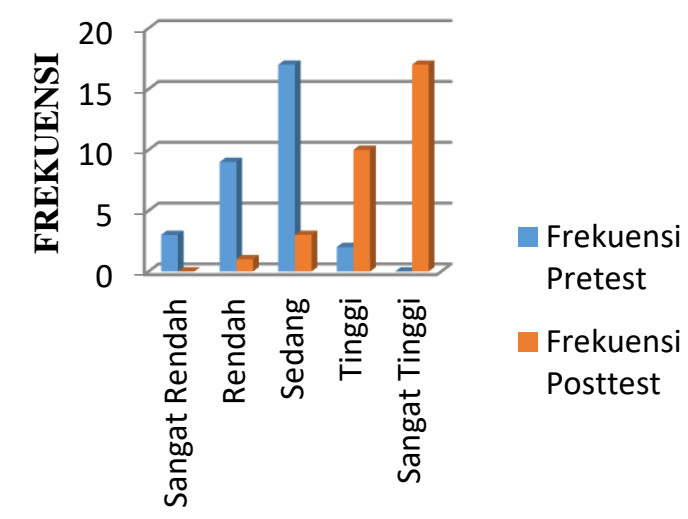

KATEGORI HASIL BELAJAR PESERTA DIDIK

Gambar 3. Diagram Kategori dan Presentase Hasil Belajar Peserta Didik Pada Pretest dan Posttest

Berdasarkan diagram kategori hasil belajar peserta didik pada gambar 3 dapat dilihat bahwa sebelum diajar dengan menerapkan game edukasi Quizizz, skor hasil belajar peserta didik berada pada kategori rendah. Sedangkan skor hasil belajar peserta didik setelah diajar dengan menerapkan game edukasi Quizizz hasil belajar peserta didik berada pada kategori tinggi.

\section{d. Hasil Analisis Uji N-Gain}

Uji N-Gain dilakukan untuk mengetahui peningkatan hasil belajar peserta didik sebelum dan setelah diajar dengan menerapkan game edukasi Quizizz pada pembelajaran apakah berada pada kategori rendah, sedang atau tinggi. Berdasarkan hasil analisis diperoleh nilai $\mathrm{g}$ sebesar 0,62, dimana nilai tersebut masuk dalam kategori sedang yaitu pada rentang $0,70>\mathrm{g}>0,30$. Hal tersebut membuktikan bahwa terjadi peningkatan hasil belajar peserta didik sebelum dan setelah diterapkannya game edukasi Quizizz pada pembelajaran di kelas X MIPA di SMA Negeri 5 Bone yang termasuk dalam kategori sedang.

\section{Pembahasan}

Jenis penelitian yang digunakan dalam penelitian ini yaitu pra-eksperimen. Dengan judul penelitian yaitu "Penerapan Game Edukasi Quizizz Terhadap Hasil Belajar Fisika Peserta Didik Kelas X MIPA di SMA Negeri 5 Bone". Dimana penelitian dilakukan dalam beberapa tahap, yaitu uji coba instrument tes hasil belajar, pemberian pretest, penerapan game edukasi Quizizz. pada pembelajaran, dan yang terakhir yaitu pemberian posttest pada peserta didik kelas X MIPA di SMA Negeri 5 Bone.

Pada awal penelitian yang dilakukan yaitu memberikan instrument tes hasil belajar kepada kelas uji coba yaitu X MIPA di SMA Negeri 5 Bone. Hal ini dilakukan untuk melihat tingakat validitas dan reliabilitas instrumen yang telah dibuat. Dimana instrumen tes hasil belajar terdiri atas 40 soal dalam bentuk pilihan ganda. Setelah dianalisis diperoleh bahwa instrumen tersebut valid karena $r_{\text {hitung }}>r_{\text {tabel }}$ dengan nilai signifikansi $<0,05$, dari 40 soal yang di uji cobakan diperoleh 30 soal valid dan 10 soal tidak valid. Selain itu, instrument tes hasil belajar tersebut juga memiliki tingkat reliabilitas yang tinggi karena diperoleh $r_{\text {hitung }}$ yang berada pada rentang 0,600-0,800 berdasarkan tabel kriteria tingkat reliabilitas item yang disajikan pada bab 2. Instrumen tes hasil belajar yang digunakan juga telah divalidasi oleh dua pakar ahli yang menyatakan instrumen layak untuk digunakan.

Instrumen tes hasil belajar yang dinyatakan valid kemudian diberikan kepada peserta didik sebagai pretest di pertemuan pertama, kemudian beberapa pertemuan berikutnya peserta didik diajar dengan menerapkan game edukasi Quizizz, setelah itu pada pertemuan terakhir instrumen tes yang sama diberikan kepada peserta didik sebagai posttest. 
Adapun hasil analisis deskriptif pada penelitian ini diperoleh bahwa skor yang diperoleh peserta didik pada posttest jauh lebih tinggi dibandingkan skor yang diperoleh pada pretest. Hal ini dapat dilihat pada tabel 4.1 dimana skor rata-rata pada pretest sebesar 13,42 dengan standar deviasi 4,20 sedangkan pada posttest skor rata-rata yang diperoleh peserta didik yaitu sebesar 23,98 dengan standar deviasi 4,70.

Pada hasil analisis uji N-Gain data hasil pengolahan yang diperoleh menunjukkan bahwa terjadi peningkatan hasil belajar peserta didik dengan nilai 0,62 yang berada pada kategori sedang.

Hasil penelitian yang dilakukan oleh (Dayanti et al., 2020; Dewi, 2019; Mulyati \& Evendi, 2020, \& Nurhayati, 2020) yang menyimpulkan bahwa terdapat peningkatan pada tiap siklusnya antara pretest dan posttest hasil belajar peserta didik, dimana pada siklus I diperoleh rata-rata hasil belajar sebesar 95 dari 36 peserta didik sedangkan pada siklus II diperoleh rata-rata hasil belajar sebesar 96 dari 36 peserta didik. Sedangkan dari hasil penelitian yang telah dilakukan diperoleh skor rata-rata pretest peserta didik sebesar 13,42 atau nilai ratarata sebesar 45 dan pada posttest peserta didik diperoleh skor rata-rata sebesar 23,98 atau nilai rata-rata sebesar 80 . dimana hasil analisis menunjukkan bahwa terdapat peningkatan hasil belajar peserta didik sebelum dan setelah diterapkannya game Edukasi Quizizz pada pembelajaran fisika. Dari hal tersebut dapat diketahui bahwa game edukasi Quizizz merupakan salah satu strategi pembelajaran yang efektif digunakan untuk meningkatkan hasil belajar fisika peserta didik.

Jadi salah satu upaya yang dapat dilakukan untuk meningkatkan hasil belajar peserta didik yaitu meningkatkan strategi pembelajaran dengan memanfaatkan game edukasi Quizizz karena dalam kegiatan pembelajaran peserta didik akan fokus pada materi yang dibahas dengan tujuan agar dapat menjawab pertanyaan kuis melalui game edukasi Quizizz yang diberikan pada bagian akhir pembelajaran.

\section{PENUTUP}

Berdasarkan hasil penelitian bahwa Jadi salah satu upaya yang dapat dilakukan untuk meningkatkan hasil belajar peserta didik yaitu meningkatkan strategi pembelajaran dengan memanfaatkan game edukasi Quizizz karena dalam kegiatan pembelajaran peserta didik akan fokus pada materi yang dibahas dengan tujuan agar dapat menjawab pertanyaan kuis melalui game edukasi Quizizz yang diberikan pada bagian akhir pembelajaran.

\section{UCAPAN TERIMAKASIH}

Ucapan terima kasih penulis sampaikan kepada Lembaga Penelitian Pengembangan dan Pengabdian Kepada Masyarakat (LP3M) Universitas Muhammadiyah Makassar yang telah memberikan dana sehingga kegiatan ini dapat terlaksana dengan baik.

\section{REFERENSI}

Arsyad, A. (2014). Media Pembelajaran. Jakarta: PT. Rajagrafindo Persada.

Citra, C. A., \& Rosy, B. (2020). Keefektifan Penggunaan Media Pembelajaran Berbasis Game Edukasi Quizizz Terhadap Hasil Belajar Teknologi Perkantoran Siswa Kelas X SMK Ketintang Surabaya. Jurnal Pendidikan Administrasi Perkantoran, 8(2), 261-272.

Dayanti, R. N., Herlambang, A. D., Wijoyono, S. H. (2020). Pengaruh Kualitas Implementasi Metode Pembelajaran Ceramah Berbantuan Powerpoint Dan Quizizz Terhadap Hasil Belajar Kognitif Dan Psikomotorik Mata Pelajaran 
Desain Grafis Percetakan di SMK Negeri 12 Malang. Jurnal Pengembangan Teknologi Informasi Dan Ilmu Komputer, 4(4), 1189-1198.

Dewi, H. (2019). Penerapan Metode Problem Based Learning Untuk Meningkatkan Ketuntasan Belajar Fisika Berbantuan Evaluasi Quizizz Di Sekolah Bersistem Kredit Semester. Jurnal Mitra Pendidikan, 10(3), 1298-1313.

Menteri Pendidikan Dan Kebudayaan Republik Indonesia. (2020). Surat Edaran Nomor 4 Tahun 2020 Tentang Pelaksanaan Kebijakan Pendidikan Dalam Masa Darurat Penyebaran Corona Virus Disease (Covid-19).

Mulatsih, B. (2020). Application Of Google Classroom, Google Form and Quizizz in Chemical Learning During the Covid-19 Pandemic. Ideguru: Jurnal Karya Ilmiah Guru, 5(1), 16-26.

Mulyati, S., \& Evendi, H. (2020). Pembelajaran Matematika Melalui Media Game Quizizz Untuk Meningkatkan Hasil Belajar Matematika SMP 2 Bojonegara. Gauss: Jurnal Pendidikan Matematika, 3(1), 64-73.

Said, M. A., Arsyad, M., Nurlina. (2015). Penerapan Model Pembelajaran Kooperatif Tipe Scramble dalam Meningkatkan Hasil Belajar Siswa Kelas X SMA Negeri 14 Makassar. Jurnal Pendidikan Fisika, 3(2), 8390.

Nurhayati, E. (2020). Meningkatkan Keaktifan Siswa Dalam Pembelajaran Daring Melalui Media Game Edukasi Quizizz pada Masa Pencegahan Penyebaran Covid-19. Jurnal Penelitian Dan Pengembangan Pendidikan, 7(3), 145-150.

Nurwahid. (2017). Pengembangan Media Tutor Pembelajaran IPA Berbasis
Web Untuk Peserta didik Kelas VIII SMPN 5 Pallangga. Jurnal Pendidikan Fisika, 5(2), 156-174.

Pohan, A. E. (2020). Konsep Pembelajaran Daring Berbasis Pendekatan Ilmiah. Purwodadi: CV. Sarnu Untung.

Purba, L. S. L. (2019). Peningkatan Konsentrasi Belajar Mahasiswa Melalui Pemanfaatan Evaluasi Pembelajaran Quizizz Pada Mata Kuliah Kimia Fisika I. Jurnal Dinamika Pendidikan, 12(1), 2939.

Ramadhani, R. (2020). Platform Asesmen Untuk Pembelajaran Daring: Teori Dan Praktik. Yayasan Kita Menulis.

Riduwan. (2015). Dasar-Dasar Statistika. Bandung: Alfabeta.

Setiawan, A. (2019). Implementasi Media Game Edukasi Quizizz Untuk Meningkatkan Hasil Belajar Matematika Materi Sistem Persamaan Linear Tiga Variabel Kelas X IPA 7 SMA Negeri 15 Semarang Tahun Pelajaran 2019/2020. Seminar Nasional Edusainstek FMIPA Unimus 2019, 167-173.

Sugiyono. (2017). Statistika Untuk Penelitian. Bandung: Alfabeta.

Sulastri, S., Asfar, A. M. I. T., Asfar, A. M. I. A., Jamaluddin., Ayuningsih, A. N., Nurliah, A. (2019). Pengaplikasian Quizizz Pada Pembelajaran Laps-Talk-Ball Dalam Melatih Kemampuan Complex Problem Solving Siswa. Prosiding Seminar Nasional Penelitian Dan Pengabdian Kepada Masyarakat.

Yana, A. U., Antasari, L., Kurniawan, B. R. (2019). Analisis Pemahaman Konsep Gelombang Mekanik Melalui Aplikasi Online Quizizz. Jurnal Pendidikan Sains Indonesia 2(7), 143-152. 